\title{
The Post-September 11 Rise of Islamophobia: Identity and the 'Clash of Civilizations' in Europe and Latin America
}

\author{
KRISTIN VANDENBELT \\ Lee College, U.S. \\ ORCID No: 0000-0002-8932-0777
}

\begin{abstract}
Following the terrorist attacks of September 11, 2001, Islamophobia exploded across 'the West,' but particularly in Europe. While Muslims were suffering attacks across Europe, the experience of Muslims in Latin America was markedly different, with almost no perceptible rise in Islamophobia. In the roughly 10 year period between the attacks of September 11, and the start of the Syrian civil war, why did Islamophobia rise in 'the West,' but not in Latin America? This article attempts to answer this question through an analysis of the civilizational identities of both regions, in particular the countries of Denmark and Argentina. While the core of Denmark's identity is being part of the 'the West,' which was 'at war' with the Muslim world during this period, Argentina defines its identity in opposition to Western countries like Britain and the U.S., leaving it outside 'the West', and Islam not seen as a threat.
\end{abstract}

Keywords: Islamophobia, Latin America, Europe, Clash of Civilizations

Insight Turkey 2021

Vol. 23 / No. 2 / pp. 145-168

Received Date: 12/12/2020 • Accepted Date: 14/03/2021 • DOI: 10.25253/99.2021232.9 


\section{Introduction}

ollowing the terrorist attacks on the World Trade Center in New York City on September 11, 2001, there was a substantial rise in Islamophobia throughout 'the West' (Europe, North and South America, Australia, and New Zealand), ${ }^{1}$ but especially in Europe. ${ }^{2}$ As Liz Fekete of the London-based Institute of Race Relations explains, "Muslims collectively are being blamed for the attacks on the World Trade Center, and there is a general punitive climate toward Muslims. This has manifested itself in a variety of ways. On the ground, there has been a rise in racial violence on Muslim targets across Europe." 3 In a region known for its commitment to the rule of law, respect for human rights, and shared values and principles of pluralist democracy; ${ }^{4}$ European Muslims - of which there were over 21 million- were now facing problems ranging from physical attacks and murder to discrimination in the job and housing markets to vandalism of Islamic centers and mosques. ${ }^{5}$ Anti-Muslim sentiment was institutionalized in Europe and, perhaps most worryingly, the increase in violence and discrimination was more and more based on issues of identity; these people were harassed because of their identity as Muslims. ${ }^{6}$

Seemingly, Muslims living throughout 'the West' had to contend with a growing racial and/or cultural prejudice and xenophobia that resulted in discrimination, marginalization, and often violence. ${ }^{7}$ The more than two million Muslims living in the United States ( 0.8 percent of the total population) and 657,000 living in Canada (two percent of the total population) were facing similar, although less virulent and widespread, forms of discrimination as those in Europe, as well as a rising Islamophobia. ${ }^{8}$ In the U.S., there were threats to burn the Qur'an (which were subsequently abandoned) and the heated and often vitriolic dispute over the building of an Islamic Cultural Center in New York City indicated a rise in Islamophobia, according to Daniel Mach of the American Civil Liberties Union (ACLU). ${ }^{9}$ According to the Canadian chapter of the Council on American-Islamic Relations (CAIR-CAN), fifteen documented acts of "desecration against an Islamic mosque or institution" occurred between September 2001 and March 2004, which they see as clear expressions of growing anti-Muslim sentiment. ${ }^{10}$

In Australia, racism toward the roughly 280,000 Muslims living there (1.5 percent of the total population) was growing, as evidenced by calls for the government to ban the niqab and the burqa; veiling is seen to be incompatible with Australia's Judeo-Christian heritage. ${ }^{11}$ In New Zealand, as a result of growing Islamophobia, the Federation of Islamic Associations of New Zealand (FIANZ) felt the need to issue a declaration reaffirming their determination to "live in peace and abide by the law" and that their "commitment to the welfare of our country shall be unquestionable." ${ }^{12}$ 
The story in Latin America (LA), ${ }^{13}$ however, was fundamentally different than that of the rest of 'the West' in that there was not a rise in Islamophobia, anti-Muslim, or anti-Islam sentiment or discrimination, or cultural and/or racial prejudice. While it is difficult to find documentation on the absence of a phenomenon, leaked WikiLeaks documents concerning the Muslim community in São Paulo expressed a belief that the Muslim community in the city offered "unique possibilities for Muslim engagement" as it "had solid achievements in integrating Muslim and Brazilian identities, making them an excellent example of how a unique Muslim Minority Community (MMC) has, by and large, carved out a positive space within a diverse Latin American country." Moreover, in interviews with the U.S. Special Representative to Muslim Communities, members of the Muslim community in São Paulo asserted that they had "no real difficulties with anti-Islamist sentiments in Brazil." 14

In addition, an examination of the U.S. Department of State's "International Religious Freedom Report" for Argentina for the years 2001-2010 revealed a consistent level of anti-Muslim violence over the years (fewer than five incidents per year); the vast majority of anti-religious acts are anti-Semitic in nature. ${ }^{15}$ Moreover, Waqas Syed, the Deputy Secretary-General for the Islamic Center of North America has stated that "[un]like Europe and North America, Latin America has been quite untouched with any of the anti-Islamic rhetoric, and the relationship between Muslims and non-Muslim Latinos can be described as excellent and strong." 16 The overall message of these documents and statements (regarding the two countries in LA with the largest Muslim populations) points to a region in which the relationship between the 1.2 million Muslims and the non-Muslim community, as well as the non-Muslim community's view of Islam and Muslims, had not changed significantly since $9 / 11 . .^{17}$

The crucial question then becomes: why? Why was there not a rise in Islamophobia and an anti-Muslim/Islam backlash in LA in the years after 9/11 as there was in the rest of 'the West?' What makes LA unique compared to the rest of 'the West' that has led to this contradictory experience with Islam and the Muslim community? Since, "when survival is uncertain, cultural diversity seems threatening," the lack of a rise in Islamophobia in LA seems to indicate that Latin Americans do not view Islam and Muslims as a threat to their culture/civilization. ${ }^{18}$ The answer seems to lie, therefore, in the principal matter 
In Europe, this 'us' vs. 'them' threat mentality has created "a situation where discriminatory or even violent behavior directed against certain minority groups is seen as more acceptable" of identity; how the people in Europe and LA construct their civilizational identities. For Charles Taylor, this is "the sense people have that the basic order by which they live, even imperfectly, is good and (usually) is superior to the ways of life of outsiders, be they 'barbarians,' 'savages,' or (in more polite contemporary language) 'less developed' peoples;"19 in Huntington's terms, they see themselves as members of which of the major civilizations? ${ }^{20}$

In order to answer the question of why there was not a rise in Islamophobia in LA, I will explore the issue of civilizational identity discussed above, engaging in a limited comparative case study of the post-9/11 and pre-Syrian crisis experiences of Denmark and Argentina. ${ }^{21}$ To that end, the paper will proceed as follows: i) the term Islamophobia will be defined and interrogated; ii) Samuel Huntington's thesis of the 'clash of civilizations' will be explored in reference to the concept of civilizational identity and in terms of the cases of Denmark and Argentina; and iii) finally, I will conclude by reviewing the main arguments of the paper and offering some thoughts on the future implications of civilizational identity for the relationship between Islam and 'the West.'

\section{Islamophobia}

In order to explain why there was not a rise in Islamophobia in LA during this period, we must first examine the concept -its meanings and manifestationsso that we can 'know it when we see it.' There is considerable debate concerning the meaning and usefulness of the concept of Islamophobia. Some scholars claim that terms like racism or xenophobia are all-encompassing enough to cover the new 'form of rejection' that is sweeping across Europe in the wake of the 9/11 attacks. ${ }^{22}$ However, in Europe, it is no longer considered politically correct to criticize immigrants due to characteristics like race, but criticizing Islam is now perceived as an 'act of courage', so the latter has replaced the former; a new concept is required to describe this new behavior. ${ }^{23}$

The standard definition of Islamophobia comes from a 1997 report by the Runnymede Trust Commission on British Muslims and Islamophobia, entitled "Islamophobia: A Challenge for us All." The report defines Islamophobia in two stages, the basic definition - "dread or hatred of Islam and therefore, to fear or dislike of all or most Muslims"- and eight components that underlie, justify, and result from the basic definition; the eight components are: i) Islam is seen as a monolithic bloc, static, and unresponsive to change; ii) Islam is seen as 


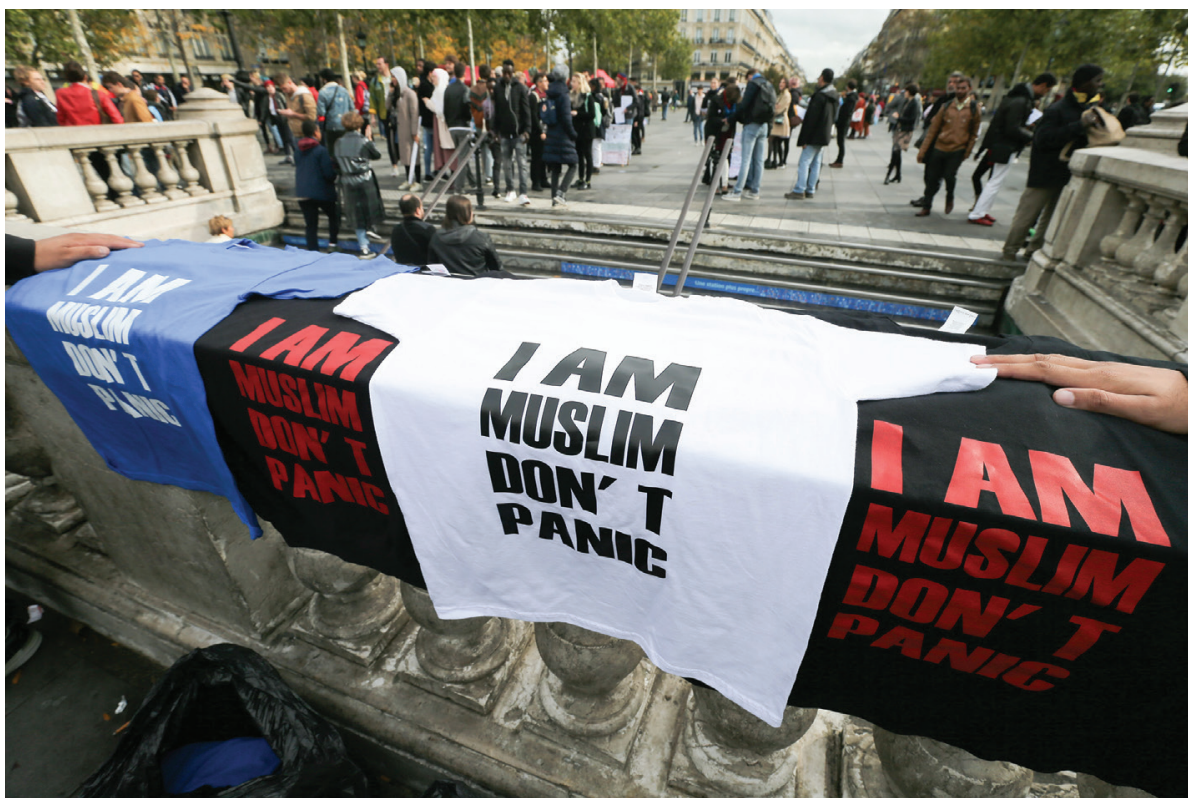

separate and 'other.' It does not have values in common with other cultures, is not affected by them, and does not influence them; iii) Islam is seen as inferior to the West. It is seen as barbaric, irrational, primitive, and sexist; iv) Islam is seen as violent, aggressive, threatening, supportive of terrorism, and engaged in a 'clash of civilizations'; v) Islam is seen as a political ideology and is used for political or military advantage; vi) Criticisms made of the West by Islam are rejected out of hand; vii) Hostility towards Islam is used to justify discriminatory practices towards Muslims and exclusion of Muslims from mainstream society; viii) Anti-Muslim hostility is seen as natural or normal. ${ }^{24}$

Components two, three, and four of this definition point to an underlying source of Islamophobia rooted in issues of identity; Islam is a separate, violent, inferior culture/civilization that is a threat to our culture/civilization.

In Europe, this 'us' vs. 'them' threat mentality has created "a situation where discriminatory or even violent behavior directed against certain minority groups is seen as more acceptable," as anticipated in the eighth component above. ${ }^{25}$ In this atmosphere of permissibility, Islamophobia has manifested in practice in various ways. Attacks against Muslim institutions, for example, became increasingly more common during this period: In Berlin on December 9, 2010, an Islamic cultural center was firebombed, the sixth arson attack on Muslim institutions in Berlin that year; eleven mosques were attacked in London after the July 7, 2005, terrorist bombings; and five mosques were firebombed in France in 2006 alone. ${ }^{26}$ Additionally, physical assaults carried out
Shirts reading "I Am Muslim, Don't Panic" are exhibited on Place de la Republique in Paris during a demonstration after a far-right politician asked a woman accompanying her son and other children on a school trip to remove her headscarf. In Paris, France on 0ctober 19, 2019.

MICHEL STOUPAK / NurPhoto / Getty Images 
against individuals believed (by the attacker) to be Muslim have increased: In Scotland, on September 10, 2007, 17-year-old Tarik Husan was stabbed while he was standing at a bus stop by a 32-year-old woman screaming "You're all terrorists;" and in Denmark, on March 19, 2008, three Danish teenagers verbally harassed (including the use of a racist slur) and assaulted (with a baseball bat and a hammer) a 16-year-old teenager of Turkish origin, Deniz Özgür Uzun, who died the next day, having sustained severe brain damage. ${ }^{27}$ As troubling as these attacks against Muslim institutions and people are, for Ekmeleddin İhsanoğlu, former Secretary-General of the Organization of the Islamic Conference (OIC), and others like him, the most disturbing element of this growing Islamophobia is the institutionalization of anti-Muslim sentiment across Europe. $^{28}$

The institutionalization of Islamophobia refers to government activity that seeks to establish some type of anti-Islam/Muslim practice or behavior as a norm for the population; usually, this takes the form of Islamophobic legislation. The French government, for example, initiated a 'national identity campaign' in 2009 to ensure an exclusive non-Muslim and non-immigrant identity for France, and also voted in September of that year to ban the wearing of the burqa and the niqab in public; President Nicolas Sarkozy called the burqa a 'walking coffin' that is 'not welcomed' in France. ${ }^{29}$ And Switzerland, despite only having four mosques with minarets and a tiny, law-abiding Muslim population, banned the building of minarets on mosques; the right-wing Swiss People's Party (SVP) claimed that "the towers would soon be springing up across the country, marking the beginning of a takeover by Sharia-supporting extremists." ${ }^{30}$ Radical-right parties, like the SVP, experienced resurgence in this period in Western Europe, attracting large voter support, and in some cases, even being included in ruling government coalitions. ${ }^{31}$

İhsanoğlu found this resurgence worrying as well because parties like the Danish People's Party (DF), the French Front National, the Italian Lega Nord, the Sweden Democrats, the Dutch Party for Freedom (PVV), and the Austrian Freedom Party, "instead of stopping this [the rise of Islamophobia], or fighting this, some of them are using this for their political ends, to gain more popular support in elections." 32 The election promises made and the campaign methods utilized by these radical right-wing populist (RRP) parties preyed on this rising Islamophobia, and help to perpetuate it throughout their respective countries. The Italian Lega Nord, for example, during the 2010 regional elections, campaigned in the Arezzo region by handing out free soap samples for voters to use "after having touched an immigrant;" they took over the regional governments of Veneto and Piemonte. ${ }^{33}$ And the Sweden Democrats party, which actually started out as a neo-Nazi movement, entered the parliament for the very first time in 2010, winning 5.7 percent of the vote with television advertisements that featured burqa-clad Muslim women knocking white Swedish 
pensioners out of the way and grabbing their state benefits. ${ }^{34}$ These RRP parties share a fundamental core of ethno-nationalist xenophobia, which incorporates a strong anti-immigration focus and an opposition to multicultural society; in that Islamophobic environment, where criticizing Islam largely replaced the practice of criticizing immigrants, RRP parties embraced an anti-Islam stance. ${ }^{35}$

As will be discussed in more detail below, these RRP parties played upon their voters' fears of Islam as a threat to their civilizational identity; they engaged in a 'political-identity mobilization' in defense of difference and 'Western' identity. ${ }^{36}$ Voters in LA did not share this fear of Islam or Muslims, reflected, in part, in the fact that the majority of the political parties, including all those in government in Argentina during this period, for example, were founded around economic, not ethnic, cleavages in society; the Justicialist Party, of which the incumbent Vice President Cristina Fernández de Kirchner was a member, is a Peronist party that represented the interests of the working and lower classes -its largest and most consistent base of support was the General Confederation of Labor, Argentina's largest trade union. ${ }^{37}$ Additionally, the major election issues in Argentina's elections involved the slowing national economy and public security; the threat to identity from the Muslim community in Argentina was a non-issue. ${ }^{38}$ As will be shown, this is a consequence of Latin Americans not viewing themselves as part of 'the West, and, as such, they are not under attack by the Islamic civilization.

\section{Civilizational Identity: A 'Clash of Civilizations'?}

In the wake of the 9/11 attacks on the U.S., "whatever spotty appeal the issue of Muslim-Christian ideological harmony had in academic and public discourse quickly faded as a more pugnacious debate pitting the Muslim and Christian worlds in a 'civilizational' clash suddenly made it to the top of the charts." ${ }^{39}$ Across Europe, there was talk of "Europeanness" as under attack from Islam and the theory of a 'clash of civilizations' between Islam and 'the West' began to gain ground..$^{40}$ As shown previously, one of the core components of Islamophobia (\#iv) is to view Islam as engaged in a 'clash of civilizations' and the RRP parties that sprang up across Europe took this theory of a 'clash of civilizations' as a rallying call. These parties not only embrace the language of the 'clash of civilizations,' but their leaders seemingly set themselves up as the 'saviors of Europe.' 


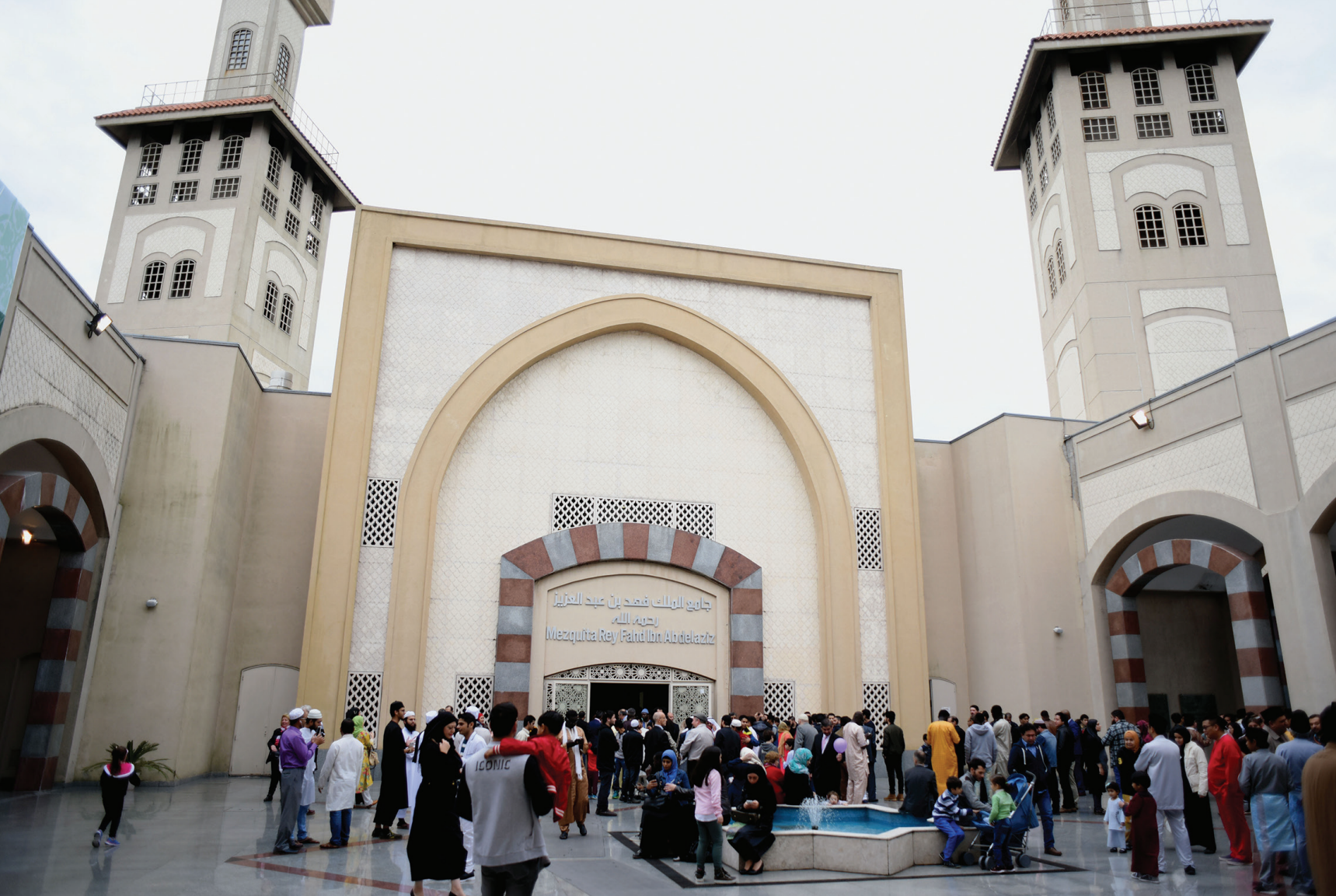

Muslims gathered at the Islamic Cultural Center in Buenos Aires, Argentina to perform Eid prayers, on June

25, 2016.

The theory of a 'clash of civilizations' is usually attributed to a 1993 article by political scientist Samuel Huntington, entitled, "The Clash of Civilizations?" In his article, Huntington argues that "the paramount axis of world politics will be the relations between "the West and the Rest..." and that "a central focus of conflict for the immediate future will be between the West and several Islamic-Confucian states." ${ }^{41}$ The primary source of conflict, according to Huntington, will no longer be economic or ideological, but cultural, given that "cultural characteristics and differences are less mutable and hence less easily compromised and resolved than political and economic ones." ${ }^{22}$

A civilization is a cultural entity, it is the highest cultural grouping of people and the broadest level of cultural identity people have short of that which distinguishes humans from other species. It is defined both by common objective elements, such as language, history, religion, customs, institutions, and by the subjective self-identification of people.... People can and do redefine their identities and, as a result, the composition and boundaries of civilizations change. ... Civilizations are nonetheless meaningful entities, and while the lines between them are seldom sharp, they are real. ${ }^{43}$

Therefore, civilizational identity is much like national identity, but on a larger scale -a Dane, for example, will identify as Danish as well as 'Western;' a member of the civilization known as 'the West.' An Argentine, on the other hand, will identify as Argentinean as well as 'Latin American.' Just like national 


\section{The only way for us to know whether or not Islamophobia is truly the consequence of a perceived civilizational threat is to understand who belongs to each civilization, and the core ideational elements of each}

identity, this is a subjective concept with which the person strongly identifies, but that can be renegotiated and redefined, although it takes time.

But, in a 'clash of civilizations,' which is based on issues of cultural characteristics and differences, where the identity of the civilization can be redefined, leading to a change in the composition and boundaries of said civilization, how are we to recognize the core elements around which the identity of each civilization is based as well as the members (countries) of each civilization? In other words, how do we know who is fighting against whom, and for what reasons? If people see themselves as members of civilization under threat (as Europeans currently seem to), then naturally hatred against members of the opposing civilization would increase (Islamophobia); however, if people do not view their civilization as under threat (as Latin Americans appear not to), then there should be no increase in hatred against another group, as there is no one threatening their civilization (no rise in Islamophobia in LA). The only way for us to know whether or not Islamophobia is truly the consequence of a perceived civilizational threat is to understand who belongs to each civilization, and the core ideational elements of each.

Huntington offers us very little guidance in answering these fundamental questions -he explains that 'the West' is based on ideas of "individualism, liberalism, constitutionalism, human rights, equality, liberty, the rule of law, democracy, free markets, the separation of church and state," ${ }^{44}$ that the European Community (now the EU, and the core of Western civilization, along with North America) "rests on the shared foundation of European culture and Western Christianity," and that Western culture and concepts "often have little resonance in Islamic, Confucian, Japanese, Hindu, Buddhist or Orthodox cultures;" ${ }^{45}$ save for a few brief discussions of 'the West', we are pretty much on our own.

Enter Ronald Inglehart, Pippa Norris, and Christian Welzel and the World Values Survey (WVS). The WVS is a worldwide network of social scientists who study peoples' changing values and their impact on social and political life in five waves of surveys in 97 countries. ${ }^{46}$ The WVS is useful for the purposes of this study because the authors also find that: 
Cross-cultural variation proves to be surprisingly coherent, and a wide range of attitudes (reflecting people's beliefs and values in such different life domains as the family, work, religion, environment, politics, and sexual behavior) reflects just two major dimensions: one that taps the polarization between 'traditional values' and 'secular-rational values;' and a second dimension that taps the polarization between survival values and 'self-expression values.' ... To a remarkable degree, these societies cluster into relatively homogeneous cultural zones, reflecting their historical heritage -and these cultural zones persist robustly over time. ${ }^{47}$

Cultures (or here, civilizations) cluster together in coherent ways according to values that can be recognized and periodically assessed; in other words, we can now identify the crucial ideational elements of each civilization and identify the membership of each.

In their 2005 work, Modernization, Cultural Change, and Democracy: The Human Development Sequence, Ronald Inglehart and Christian Welzel did just that, creating a "Cultural Map of the World" 48 that placed all of the countries in the WVS into their appropriate civilization according to their scores on both the 'traditional/secular-rational' values and 'survival/self-expression values' dimensions. The resulting graph is open to a wide range of interpretations,

Mogens Camre, a member of Parliament for the DF between 1999 and 2009, has expressed an 'us' versus'them,' 'clash of civilizations' message on a number of occasions but following the argument put forward by Ronald Inglehart and Pippa Norris in "The True Clash of Civilizations," the "real fault line between the West and Islam" is over social, not political values. ${ }^{49}$ They explain that "at this point in history, societies throughout the world (Muslim and Judeo- Christian alike) see democracy as the best form of government,"

but on social issues like gender equality and sexual liberation, "as younger generations in the West have gradually become more liberal on these issues, Muslim nations have remained the most traditional societies in the world." 50 Therefore, the 'traditional/secular-rational values' dimension, which reflects the contrast between countries where religion is very important and those in which it is not, provides us with the most useful information in determining the core ideational values and member-states of 'the West.'

As we can see on Inglehart and Welzel's "Cultural Map of the World," the countries of the 'Protestant Europe,' 'Catholic Europe' and 'English Speaking' sections make up the civilization identified by Huntington as 'the West' (Map 1). These countries, such as Denmark, share the foundational historical, cultural, and value-elements discussed by Huntington and are locked in a 'clash of civ- 
ilizations' with Islam; therefore, we should see a rise in Islamophobia in these countries. The majority of the countries in LA, however, seem to fall outside of 'the West' when it comes to elements on the 'traditional vs. secular-rational values' dimension $(-0.5$ to -2.0$)$. Societies with more traditional values (on the lower end of the scale), tend to "emphasize the importance of parent-child ties and deference to authority, along with absolute standards and traditional family values, and reject divorce, abortion, euthanasia, and suicide. These societies have high levels of national pride, and a nationalistic outlook." ${ }^{51}$ While not every country within each civilization shares these values to the same degree, these are general civilization-wide trends.

Map 1: Inglehart-Welzel Cultural Map Wave 5

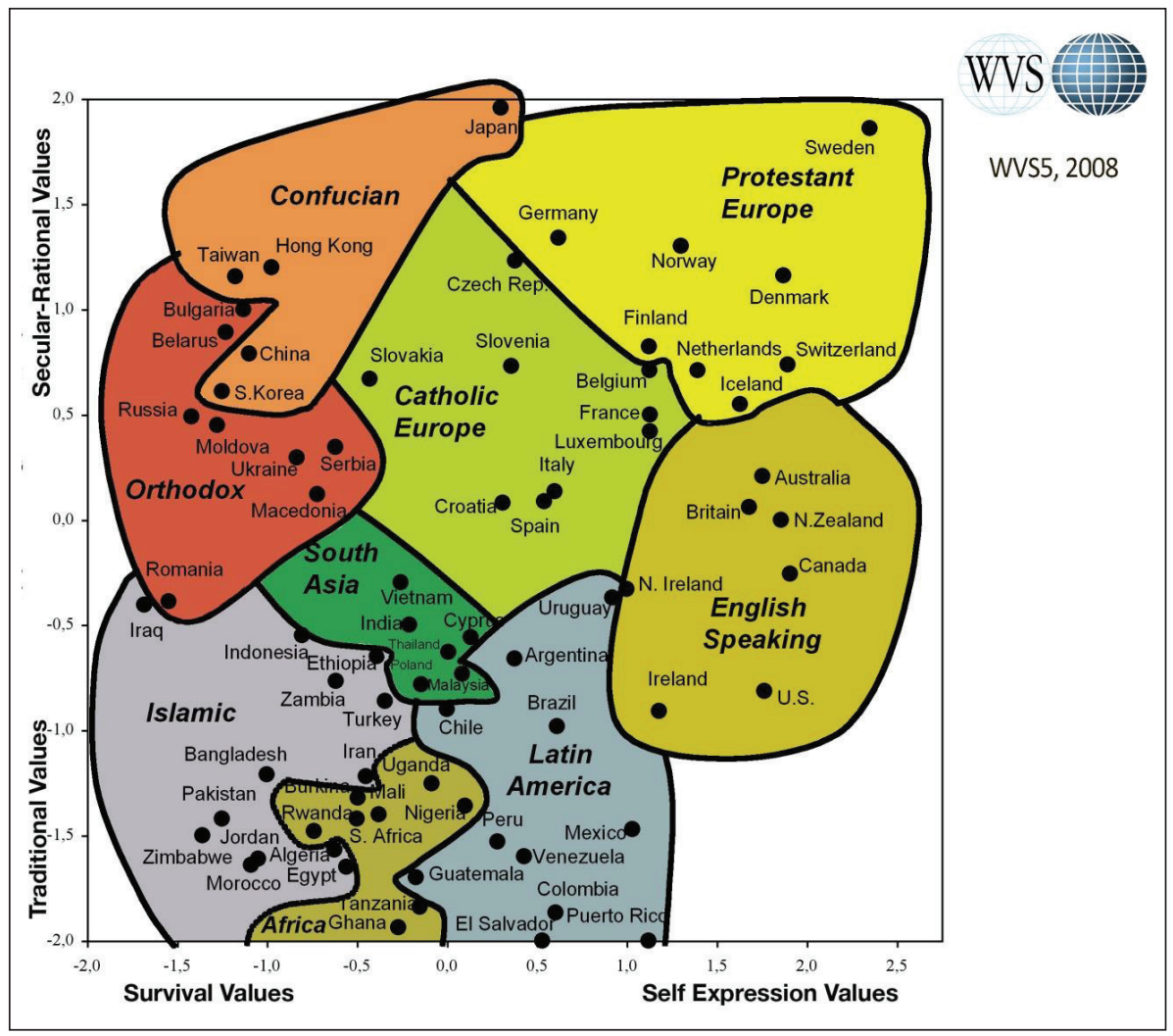

Source: World Values Survey ${ }^{52}$

Thus, in a 'clash of civilizations' in which religion has become the fundamental ideational element for each civilization, ${ }^{53}$ countries belonging to the LA civilization should not see a rise in Islamophobia for two reasons: they do not identify themselves as members of 'the West', which is engaged in the 'clash of civilizations' with Islam, and they share many of the same fundamental traditional values as the Islamic civilization, so Muslims residing in their countries 
In all aspects of their message, the DF paints Islam as an evil, primitive civilization that is a threat to the Western culture and values that Danes, as proud members of 'the West,' hold dear

are not viewed as a foreign threat to national culture, which cannot be integrated. While these assertions are based on one interpretation of the WVS data as applied to Huntington's 'clash of civilizations' thesis, case study evidence from two countries -Denmark and Argentina- which are members of 'the West' and LA civilizations, respectively, should help to show that it is civilizational identity that is one of the main factors at the heart of the post 9/11 and pre-Syrian crisis rise in Islamophobia in Europe, and the lack of a rise in Islamophobia in LA during the same time period.

\section{Case Studies}

\section{Denmark}

Denmark, which name's means 'Borderlands of the Danes', represents the ideal European nation-state, in that a single ethnonational group (the Danes) built a state (Denmark was actually created during the $6^{\text {th }}$ through $9^{\text {th }}$ centuries) and since 1864 has maintained, or did until recently, a rather homogeneous population. ${ }^{54}$ Additionally, Denmark joined the EU in 1973 during the first wave of enlargement; basically, Denmark is a quintessential European country that is firmly entrenched within 'the West.' Two post-9/11 developments illustrate Denmark's self-identification as a member of 'the West' that is engaged in a 'clash of civilizations' with Islam: the rise of the RRP party, the Danish People's Party (DF), and the 2005 cartoon controversy in which a Danish newspaper, Jyllands-Posten, published 12 cartoons of the Prophet Muhammad.

As part of his 'clash of civilizations' thesis, Huntington argued that over time governments and groups will decreasingly be able to mobilize support and form coalitions on the basis of ideology, so they "will increasingly attempt to mobilize support by appealing to common religion and civilization identity." 55 The rhetoric and growing popularity of the DF perfectly illustrates Huntington's assertion. The DF was founded in 1995 as a break-off from the Danish Progress Party, a right-wing party that supported radical tax cuts and deep cuts in government spending. Over time, the party "began to harden its position against Islam significantly, playing to popular concerns about the threat posed by Muslim countries," and to "depict Islam as a totalitarian and violent ideology whose destructive effects posed a deadly threat to Western democratic principles and values from within." ${ }^{\text {. }}$ 
Mogens Camre, a member of Parliament for the DF between 1999 and 2009, has expressed an 'us' versus 'them,' 'clash of civilizations' message on a number of occasions. In 2001, at the DF annual convention, he said "what we are facing with is not just a short-term military operation. It is a question of driving this evil ideology out of the Western civilization. Islam should never get a place in our countries;" and at the same meeting in 2004, "let me state it clearly: Muslims ought to live in 'Muslimland' -and that's not here." Pia Kjærsgaard, the Chairperson of the party, has taken the message even farther, responding to Swedish criticism over a proposal to tighten immigration laws in Denmark by commenting, "if they want to turn Stockholm, Gothenburg or Malmoe into a Scandinavian Beirut, with clan wars, honor killings, and gang rapes, let them do it. We can always put a barrier on the Oresund Bridge;" 57 and saying in an interview with Weekly Commentary on June 13, 2005:

Not in their wildest imagination would anyone [in 1900] have imagined, that large parts of Copenhagen and other Danish towns would be populated by people who are at a lower stage of civilisation, with their own primitive and cruel customs; like honour killings, forced marriages, halal slaughtering, and blood-feuds. This is exactly what is happening now. Thousands upon thousands of people who spiritually, culturally, and with regard to civilization, are plainly still in the year 1005 instead of 2005, that have come to a country [Denmark] that left the dark ages hundreds of years ago. ${ }^{58}$

In all aspects of their message, the DF paints Islam as an evil, primitive civilization that is a threat to the Western culture and values that Danes, as proud members of 'the West', hold dear. Their message seems to be working as they have increased their total vote, their percentage of the popular vote, and their number of seats in the parliament in every election in which they have run going from 7.4 percent of the popular vote and 13 seats in parliament in 1998 to 13.8 percent of the popular vote and 25 seats in parliament in 2007. Plus, from 2001, the DF was part of the ruling Conservative-Liberal coalition government, together with the Conservative People's Party and Venstre. The DF, and other RRP parties like it, has tapped into a "highly public discourse about the limits of cultural diversity and a European fixation with social homogeneity that eschews pluralism;" Islam is fundamentally at odds, and is irreconcilable with all that is Danish and Western. ${ }^{59}$

Never was this tension between social homogeneity and cultural pluralism seen so clearly as in the wake of the cartoon controversy, when Denmark became the 'flashpoint in the growing culture wars between Islam and the West.' 60 On September 30, 2005, Danish newspaper Jyllands-Posten commissioned and published 12 cartoons depicting images of the Prophet Muhammad, which is considered blasphemous and is forbidden in Islam. Almost immediately there were negative reactions to the publications, organizations like the OIC 
condemned the publication, and a group of 11 ambassadors, who represented over half a billion Muslim people, asked to meet with Danish Prime Minister Anders Fogh Rasmussen to discuss the incident. When the Prime Minister refused, the story went global; violent protests began to spring up all over the world and the cartoonists as well as Flemming Rose -the editor of the paper who had commissioned the cartoons- received numerous death threats. ${ }^{61}$

Rose tried to explain that the cartoons were meant to be a way of integrating and incorporating the Muslim community in Denmark into the culture, not about provoking, demonizing, or stereotyping Muslims. In a Washington Post Op-Ed piece he explained, that

We have a tradition of satire when dealing with the royal family and other public figures, and that was reflected in the cartoons. The cartoonists treated Islam the same way they treat Christianity, Buddhism, Hinduism, and other religions. And by treating Muslims in Denmark as equals they made a point: We are integrating you into the Danish tradition of satire because you are part of our society, not strangers. The cartoons are including, rather than excluding, Muslims. ${ }^{62}$

However, partly as a result of the Prime Minister's behavior, and partly as a result of the Western media, the language of the debate quickly changed into that of a 'clash of civilizations' into one of the Muslim world having a problem, not the West. Danish Prime Minister Rasmussen made it clear, that to him, Denmark and the West have freedom of speech, while 'you guys' in the Muslim world do not. This is a problem of "immigrants from Muslim countries who refuse to recognize Danish culture and European norms." In other words, 'We' in the West are civilized, and 'You' in the Muslim world are not. ${ }^{63}$

In response, several Islamic governments and organizations, including the Muslim Brotherhood and the Muslim Council of Britain, issued denunciations and a boycott of Danish goods began across the Muslim world. Across the Western world, leaders were quick to show their support, with Austrian Foreign Minister Ursula Plassnik declaring, "We have expressed a spirit of solidarity with our northern colleagues, as well as our belief and attachment to the freedom of the press and the freedom of expression as part of our fundamental values, and the freedom of religious beliefs;" and her French colleague Philippe Douste-Blazy added that "We have all declared our solidarity with the Danes." ${ }^{64}$ In the United States, conservatives like Michelle Malkin, Judith Apter Klinghoffer, Glenn Reynolds, and Seth Greenland of the Huffington Post, worked on a 'Support Denmark' and 'Buy Danish' campaign to counteract the Muslim boycott of Danish goods and so that we don't have to see "Westerners capitulating to Muslim demands regarding one of the most fundamental tenets [freedom of speech] of our society." ${ }^{65}$ In the end, the fallout over the pub- 
lication has died down, although tensions get stirred back up every time the cartoons are reprinted in another newspaper or book.

\section{Argentina}

On the other side of the civilizational map, lies LA and its quintessential state-nation, Argentina. Officially declaring its independence from Spain on July 9, 1816, like most colonial states, Argentina is considered a state-nation in that the state preceded and molded the nation, which consists of several ethnic groups. ${ }^{66}$ Unlike in Denmark and other nation-states, for Argentina, "heterogeneity is conceived as part of the nation." ${ }^{67}$ The founding experience of colonialism and the high influx of migrants early in Argentina's history promoted cultural hybridization and mutual involvement. ${ }^{68}$ Essentially, "Latin America's experiences of colonialism, neo-colonialism and internal colonialism mean that its national 'identities' have always been multifold, created and re-created in a continuous process of negotiation and renegotiation with both the others without and the others within." ${ }^{69}$ The result of this ongoing process of defining identity has been an internal identity of inclusion, and external identity of Hispanoamericanismo and anti-imperialism/ Americanization. ${ }^{70}$

This internal identity of inclusion is partly related to the process by which the Muslim community developed in Latin America. By 2010 there were roughly 2.3 million Muslims in South America and only about 50 percent of those were migrants. The rest were converts from Latin America or the descendants of Muslim immigrants. The original Muslim immigrants came to Latin America in two waves: first, in the $15^{\text {th }}$ century when slaves were brought from Africa; and second, between 1878 and 1924 with a wave of migration from mainly Syria, Lebanon, and Palestine. These migrants largely settled in Argentina, Brazil, Colombia, and Venezuela. As a result of these waves of migration, and conversion, Brazil and Argentina have the two largest Muslim populations in Latin America. Given the long history of Muslims in Latin America, and the large numbers of converts, the Latin American Muslim community is inclusive of many ethnic groups and is well integrated into the community -seen as part of 'us' instead of an outsider 'them.".

The relationship between race, ethnicity, and religion in LA, just as it is in the U.S. or any other country of immigration, is complicated. The case of the Argentine President Carlos Menem (1989-1999) offers an excellent illustration of the complicated nature of this relationship. Born to Syrian immigrant 
For Latin Americans, the U.S. represents 'the West,' while also serving as their identity 'other,' therefore, to be Latin American is almost to be anti-Western parents in the La Rioja Province of Argentina, Menem was unofficially the country's first Muslim president. $^{72}$ At the time that Menem was running for president, the Argentine constitution required that the presidential and vice-presidential candidates be of the Catholic faith, and Menem converted to Catholicism shortly before his election as president. ${ }^{73}$ While technically a Catholic, the population never fully accepted him as such, especially because his wife never converted and practiced her faith openly, he appropriated state land for the building of a Saudi Arabian mosque in Buenos Aires, and called a special assembly to reform the national constitution; the provision requiring the president to be Catholic was removed. ${ }^{74}$

The Argentine population, therefore, was open and accepting enough of people of other ethnicities and faiths to elect a Syrian Muslim to the highest political office in the land, although once in office, anti-Muslim bigotry toward Menem raised its ugly head. In criticizing Menem's policies and heavy reliance on governance by decree, an opposition legislator referred to him as 'a Muslim deity' and the Archbishop of Buenos Aires fought against the building of the Saudi mosque by calling Islam one of the 'great heresies' and described Prophet $\mathrm{Mu}-$ hammad and the Saudis as "degraded idolaters from savage Arabia."75 Across LA, we see a conflictual and ever-evolving relationship with ethnicity, religion, and identity; quite similar, in fact, to that found in the U.S. Racism, xenophobia and Islamophobia exist across LA, but those sentiments have not increased after 9/11.

Argentines, overall, are very nationalistic, but there is little agreement on what the basis for that nationalism is; conservative elites historically have tried to mold the idea of the nation around the two pillars of the Roman Catholic Church and Spanish tradition. The modern 'obsessive search for a national soul' finds the nation oscillating between seeing itself as a Latin American mestizo nation and a highly-educated Western nation, ${ }^{76}$ although the Argentine conception of a Western nation is not the same conception held by those countries in 'the West;' for Argentina, race/ethnicity and nation are not connected as they are in Europe. Nationalism here draws upon a rhetoric of inclusion, rather than exclusion, and it actually allows marginalized persons (like indigenous peoples) to use the rhetoric of nationalism to renegotiate and better their position in society. The region's experience with neo-imperialism means that from the early 1900s onwards, nationalism "often assumed a left-leaning, developmentalist, anti-imperialist and popular emphasis." 77 In addition, the Catholic Church has had a profound and deep-seated influence on the for- 


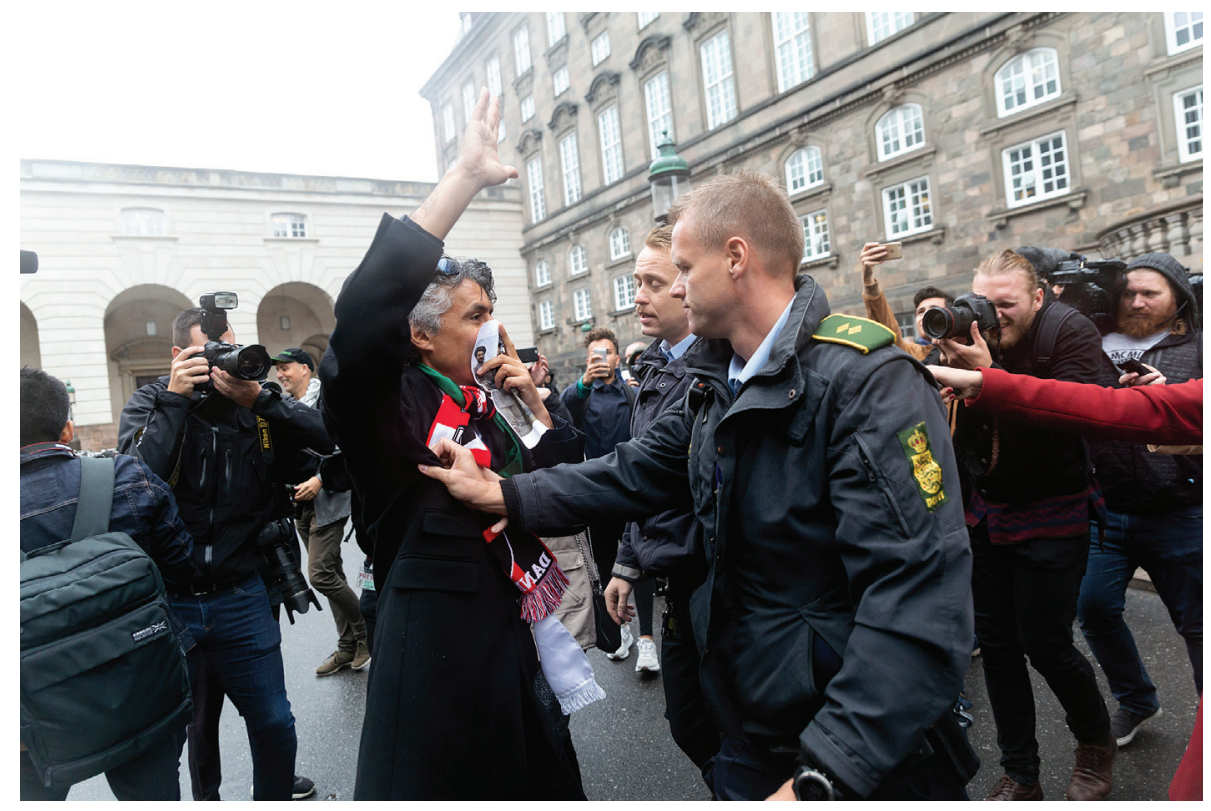

Danish police interrupt the French-Algerian businessman, Rachid Nekkaz as he speaks in front of the Danish Parliament and offers to pay the fines for Muslim women who have been in violation of the country's new burqa ban. Copenhagen, Denmark on September 11, 2018.

mation of society and the nation in Argentina and LA, which can be seen in their displaying greater support for religious authorities playing an active societal role than do Western societies; a support they share with many Muslim societies. $^{78}$

However, perhaps most importantly, identity in Argentina is seen as two things: anti-imperial (especially anti-Britain and anti-American) and Hispanoamericanismo (Latin American). Given their colonial history and their proximity to the U.S., LA countries have historically "sought to distinguish themselves from ... various European countries (Spain, France, Britain)" and "the United States," and have developed a complex transnational regional identity. ${ }^{79}$ For Argentina, the United Kingdom (UK) serves as the main identity 'other;' to be Argentine is to be anti-UK. This stems from their long-running dispute (going back to 1833) over the Malvinas (Argentine name)/Falkland Islands (British name). The fight over the Malvinas is a core element of Argentine identity, one that places it most definitely outside of 'the West', because, as explained by the former Argentine President Cristina Fernández de Kirchner, there still "subsists a colonialist enclave a few hundred kilometers from our shores [the Malvinas]" and colonialism is something perpetrated by 'the West' on those outside 'the West', non-Westerners. ${ }^{80}$ In terms of Hispanoamericanismo, this can be seen in Argentina taking leadership positions in regional organizations like the Common Market of the South (Mercosur) and the Union of South American Nations (Unasur); increasingly, to be Argentine is to be (Sudamericana) South American. ${ }^{81}$ 
Through open communication, consistent messaging about belonging and being a part of 'us,' along with working to build positive ties between the Muslim and non-Muslim communities, this Islamophobia can be overcome and does not have to be a given
For most Latin Americans, however, the main oppositional other is the U.S.; in LA citizenship creates a 'cultural space to resist Americanisation.' ${ }^{2}$ This can be seen most vividly in the reaction of Muslim Latin Americans to the Danish cartoon controversy in 2005. While most Muslims burned Danish and Norwegian flags in protest, Muslims in Venezuela, for example, burned American flags in protest of this 'Western' affront to their beliefs. For Latin Americans, the U.S. represents 'the West,' while also serving as their identity 'other', therefore, to be Latin American is almost to be anti-Western.

Finally, Huntington asserted, in his 'clash of civilizations' thesis, that "groups or states belonging to one civilization that becomes involved in war with people from a different civilization naturally try to rally support from other members of their own civilization ... the 'kin-country' syndrome is ... the principal basis for cooperation and coalitions." ${ }^{83}$ Hence, if LA identifies itself as part of 'the West', then we should see it rallying to the support of its western friends and allies. But this is not at all what we see, as countries in LA continue to strengthen their bonds with the Islamic world. In October 2010, President Chavez of Venezuela and President Ahmadinejad of Iran "hailed what they called their strong strategic relationship" and "saying they are united in efforts to establish a 'new world order' that will eliminate Western dominance over global affairs." ${ }^{84}$ Additionally, in early December 2010, Argentina and Brazil recognized the independent state of Palestine, with borders predating those annexed by Israel in the 1967 war; Uruguay announced that it would follow suit next year. So far, 'mostly Muslim and former Soviet bloc countries' have done the same, and some see the move as signaling 'a growing Latin American relationship with Israel's arch-enemy, Iran. ${ }^{85}$

Rather than a LA that is firmly embedded in 'the West' and allied with its Christian brethren in a fight against the evil Islamic threat, we see a clearly non-Western LA that seemingly views itself as decidedly anti-Western. The oppositional element of LA identity, based mainly against the U.S. (seen most clearly by the Venezuelan Muslims burning the U.S. flag), as well as the important influence of religion in the region (as evidenced by its position on the 'traditional vs. secular-rational values' dimension of the "Cultural Map of the World") appears to overcome any affinity or kinship that might be felt with 'the West' based on political values like democracy, free markets, liberty, etc. National identity is 
defined by heterogeneity and inclusiveness, so the Muslim communities in LA are not seen as a threat to identity, especially as they are not a threat to Latin America's civilizational identity; thus, Islamophobia has not risen in the region.

\section{Conclusion}

The perceived existential threat posed by Islam to European civilizational identity has led to a rise in Islamophobia in countries across the region. For Latin Americans, however, Islam poses no such threat and, consequently, Islamophobia has not taken hold in the region. The crucial difference lies in how the people of these two regions identify themselves: Europeans see themselves as firmly entrenched members of 'the West,' while Latin Americans view themselves as outside of and often in opposition to 'the West.' Therefore, Europeans are actively engaged in a 'clash of civilizations' with Islam, whereas, Latin Americans are bystanders, or sometimes even active participants on behalf of the Islamic civilization. Either way, Islam and Muslims are not dangerous, treacherous entities to be feared, hated, and attacked.

This is where this article, hopefully, makes its most useful contribution. Sadly, Islamophobia is rarely discussed outside of Europe and North America -the global 'West' the same areas that saw a massive spike in Islamophobia following the attacks of September 11. This leads many to believe that Islamophobia is a given -a natural phenomenon that will occur anywhere large communities of Muslims live side-by-side with non-Muslims. But, as soon as we look elsewhere in the world, as this article does with Latin America, the reality of Muslims living in those areas paints a very different picture. This article shows that Islamophobia is not a given outside of the 'West,' and that Islam and Muslims can be embraced and welcomed within majority non-Muslim communities.

Moreover, this article offers countries within the global 'West' a guide, a way for them to change their relationships with their growing Muslim communities and potentially end the outbreak of Islamophobia in the region. Rather than painting Islam and Muslims as an existential threat, governments should look to countries like those in Latin America which have successfully engaged with, and integrated, their Muslim communities within their society. Through open communication, consistent messaging about belonging and being a part of 'us', along with working to build positive ties between the Muslim and non-Muslim communities, this Islamophobia can be overcome and does not have to be a given. Unfortunately, for the more than 21 million Muslims currently living in Europe, identities take quite a long time to become solidified, recognized, and accepted by the community at large. ${ }^{86}$ In the meantime, as Huntington asserted, we will have "a world of different civilizations, each of which will have to learn to coexist with the others." 87 


\section{Endnotes}

1. For this examination of the rise of anti-Muslim sentiment, a 'West' comprised of Europe, North and South America, Australia and New Zealand is appropriate because the conflict is most often framed (by the media, politicians, and scholars) as a Huntingtonian 'Clash of Civilizations' between Islam and 'Christian-Oriented Nations' or between 'Islamic Cultures and those of the Christianity-based Western Societies.' John P. Synott, Global and International Studies: Transdisciplinary Perspectives, (Victoria: Social Science Press, 2004), p. 289.

2. For the purposes of this paper, the region of 'Europe' will be demarcated according to the boundaries proposed by Samuel Huntington in "The Clash of Civilizations." Huntington's image of Europe follows closely that of the current EU (27 member-states) along with the four Western European non-members (Iceland, Liechtenstein, Norway and Switzerland), and the candidate countries of Albania, Montenegro, Northern Macedonia, and Serbia. The key to this definition of Europe is the shared common experiences and values (like religion); this is why Turkey, although an EU candidate country, is not considered a part of 'Europe'. "Anti-Muslim Sentiment Is Becoming Institutionalized in West, Islamophobia Like 1930s Anti-Semitism: Islamic Forum Head," AFP, (November 5, 2010), retrieved March 25, 2020, from http:// www.alarabiya.net/articles/2010/11/05/124969.html; "States Want Investigation into Western Media on Religion, OIC Wants UN Action on West's 'Islamophobia,"' Reuters, (June 16, 2010), retrieved March 25, 2020, from http://www.alarabiya.net/articles/2010/06/16/111522.html; Jean -Yves Camus, "The Use of Racist, Anti-Semitic and Xenophobic Elements in Political Discourse: High-level Panel Meeting on the Occasion of the International Day for the Elimination of Racial Discrimination," European Commission against Racism and Intolerance, (March 21, 2005), retrieved March 25, 2020, from https://tandis.odihr.pl/ bitstream/20.500.12389/19625/1/02591.pdf; Anthony Faiola, "Anti-Muslim Feeling on the Rise in Sweden," The Seattle Times, (November 6, 2010), retrieved March 25, 2020, from https://www.seattletimes. com/nation-world/anti-muslim-feeling-on-the-rise-in-sweden/.

3. Leela Jacinto, "Is Islam Endangering 'Europeannesess?' As Muslim Population Increase, 'Islamophobia' Rises in Europe," ABC News, (December 7, 2004), retrieved March 27, 2020, from http://abcnews.go.com/ International/story?id=289575\&page=1; See also, Leela Jacinto, "Islam vs. Christianity in a Holy War? Islamic and Christian Extremists Fight a Vitriolic War of Words," ABC News, (January 15, 2010), retrieved March 27, 2020, from http://abcnews.go.com/International/story?id=79706\&page=1.

4. Camus, "The Use of Racist, Anti-Semitic and Xenophobic Elements in Political Discourse," p. 9.

5. "Mapping the Global Muslim Population: A Report on the Size and Distribution of the World's Muslim Population," Pew Research Center, (October 7, 2009), retrieved from https://www.pewforum. org/2009/10/07/mapping-the-global-muslim-population/, p. 22.

6. Faiola, "Anti-Muslim Feeling on the Rise in Sweden;" Elias L. Khalil, "Why Europe? A Critique of Institutionalist and Culturalist Economics," Journal of Economic Surveys, Vol. 26, No. 2 (October 2010).

7. Tzvetan Todorov, The Fear of Barbarians: Beyond the Clash of Civilizations, (Chicago: The University of Chicago Press, 2010), p. 150; Camus, "The Use of Racist, Anti-Semitic and Xenophobic Elements in Political Discourse," p. 11.

8. "Mapping the Global Muslim Population," p. 25; "Anti-Muslim Sentiment Is Becoming Institutionalized in West; "'Islamophobia Accusations Spark Debate on Canada Press Freedom," AFP, (April 27, 2008), retrieved March 29, 2020, from https://iqna.ir/en/news/1647057/islamophobia-accusations-spark-debate-on-canada-press-freedom.

9. Mark Egan, "Fears Rise Over Growing Anti-Muslim Feeling in U.S," Reuters, (September 12, 2010), retrieved March 27, 2020, from http://www.reuters.com/article/idUSTRE68B10920100912.

10. "International Religious Freedom Report 2004: Canada," U.S. Department of State, Bureau of Democracy, Human Rights, and Labor, retrieved from https://2009-2017.state.gov/j/drl/rls/irf/2004/35529.htm.

11. Janet Phillips, "Muslim Australians," The Parliament of Australia E-Brief, (March 6, 2007), retrieved March 30, 2020, from https://www.aph.gov.au/About_Parliament/Parliamentary_Departments/Parliamentary_Library/Publications_Archive/archive/MuslimAustralians; "Ban Islamic Extremist Preachers: MP," The Sydney Morning Herald, (July 5, 2010), retrieved March 30, 2020, from https://www.smh.com.au/ national/ban-islamic-extremist-preachers-mp-20100705-zxj2.html. 
12. Chris Carter, "Minister Applauds Declaration from NZ Muslims," The Official Website of the New Zealand Government, (January 16, 2003), retrieved March 30, 2020, from https://www.beehive.govt.nz/release/minister-applauds-declaration-nz-muslims.

13. When Reference is made to LA or the Region, it is with full understanding and recognition that "regions are indeed social constructions and/or political projects." Olivier Dabéne, The Politics of Regional Integration in Latin America Theoretical and Comparative Explorations, (New York: Palgrave Macmillan, 2009), p. 9. For the purposes of this political project, I will be using the definition provided by Thomas Skidmore and Peter Smith in Modern Latin America. They define the LA region as those territories in the Americas where the Spanish or Portuguese languages prevail: Mexico, most of Central and South America and Cuba, the Dominican Republic and Puerto Rico, in the Caribbean. LA is, therefore, those parts of the Americas that were once part of the Spanish or Portuguese Empires; In other words, Spanish America and Brazil. See, Thomas Skidmore and Peter Smith, Modern Latin America, $6^{\text {th }}$ ed., (Oxford: Oxford University Press, 2005), pp. 1-10.

14. "WikiLeaks: US Consulate in Brazil Sought to Engage Muslims," Latin American Herald Tribune, (December 12, 2010), retrieved April 2, 2020, from http://www.laht.com/article.asp?Articleld=380393\&Categoryld=14090.

15. Reports can be retrieved from https://www.refworld.org/docid/4cf2d0b873.html.

16. Vincent Lofaso, "Argentina's Muslim Minority," Council on Hemispheric Affairs, (December 13, 2016), retrieved March 26, 2020, from https://www.coha.org/argentinas-muslim-minority/.

17. "Mapping the Global Muslim Population," p. 25; I want to be very clear here that I am only arguing that anti-Muslim sentiment and Islamophobia has not increased in LA between 9/11 and the Syrian crisis, not that there are not "high levels of bigotry directed against" Muslims in LA (Gladys Jozami, "The Return of the 'Turks' in 1990s Argentina," Patterns of Prejudice, Vol. 30, No. 4 (1996), p. 70.) or that all ethnic prejudice has been eradicated from the region (Ignacio Klich and Jeffrey Lesser, "Introduction: 'Turco'Immigrants in Latin America," The Americas, Vol. 53, No. 1 (1996), p. 1-14), because that is very much not the case. As Klich and Lesser explain, Latin Americans have an "irritating penchant to oversimplify by way of grouping together under a single rubric immigrants from various even conflicting regional, national, and/or ethnoreligious backgrounds." This can be seen most clearly in the crude and derogatory misnomer -'turco'- used in Argentina to describe Arabs, Armenians and Jews. In spite of Arab and Armenian protestations to encourage Latin Americans to refrain from using the term, 'powerful nativists oppose their efforts.' See, Klich and Lesser, "Introduction," pp. 2, 4.

18. Ronald Inglehart and Christian Welzel, Modernization, Cultural Change, and Democracy: The Human Development Sequence, (Cambridge: Cambridge University Press, 2005), p. 54.

19. Charles Taylor, "Religious Mobilizations," Public Culture, Vol. 18, No. 2 (2006), p. 286.

20. Samuel Huntington, "The Clash of Civilizations?" Foreign Affairs, Vol. 72, No. 3 (1993), p. 26.

21. These cases were intentionally chosen due to their values on one critical explanatory variable -percentage of the total population that is Muslim. Denmark and Argentina are dissimilar on almost all of the typically important indicators -system of government, size of territory, total population- but the Muslim population of each country (88,000 in Denmark and 784,000 in Argentina) accounts for roughly 2 percent of the total population in each country at the time period under study ("Mapping the Global Muslim Population," pp. 31-32). While it is usually considered inadvisable to select observations on the explanatory variables, King, Keohane, and Verba explain that when undertaking an exploratory study, it can be "appropriate to control for the variable in which we are not primarily (or currently) interested." By holding the specific control variable nearly constant, we can "focus on the explanatory variables of interest ... without suffering the effects of omitted variable bias" (Gary King, Robert O. Keohane, and Sidney Verba, Designing Social Inquiry, (Princeton: Princeton University Press, 1994), p. 140). Analyzing the cases of Denmark and Argentina permits me to control for the variable, 'size of the Muslim population as a percentage of the total population, which has already been identified as having an influence on inter-ethnic group interaction (Milton J. Yinger, Ethnicity: Source of Strength? Source of Conflict? (Albany: State University of New York Press, 1994), p. 194), allowing me to focus on other explanatory variables of interest- those that vary across the cases- such as identity, that may be responsible for the dissimilar outcomes in their respective regions. 
22. Nazila Ghanea, "Phobias' and Isms:' Recognition of Difference or the Slippery Slope of Particularisms?" in Nazila Ghanea, Alan Stephens, and Raphael Walden (eds.), Does God Believe in Human Rights? Essays on Religion and Human Rights, (Leiden: Martinus Nijhoff, 2007), pp. 211-232.

23. Todorov, The Fear of Barbarians, p. 9.

24. Gordon Conway, Islamophobia: A Challenge for Us All, (London: Runnymede Trust Commission on British Muslims and Islamophobia, 1997).

25. "The Use of Racist," p. 11.

26. "Berlin Islamic Cultural Center Hit by Firebomb," The Jerusalem Post, (December 9, 2010), retrieved April 5, 2020, from http://www.jpost.com/Headlines/Article.aspx?id=198723; Ted Stahnke, Paul LeGendre, Innokenty Grekov, Michael McClintock, and Alexis Aronowitz, "Violence against Muslims: 2008 Hate Crime Survey," Human Rights First, (2008), retrieved from https://www.humanrightsfirst.org/ sites/default/files/FD-081103-hate-crime-survey-2008.pdf, p. 3.

27. Stahnke, et al., pp. 7-8.

28. "Anti-Muslim Sentiment Is Becoming Institutionalized in West."

29. Ramzy Baroud, "Europe's Identity Crisis: A Growing anti-Muslim Sentiment throughout Europe," Global Research, (December 24, 2009), retrieved March 30, 2020, from http://www.globalresearch.ca/ index.php?context=va\&aid=16655; Peter Allen, "France's Senate Backs National Assembly and Bans Women from Wearing the Burka in Public," Daily Mail Online, (September 15, 2010), retrieved April 4, 2020, from http://www.dailymail.co.uk/news/worldnews/article-1312016/Frances-Senate-bans-women-wearing-burka-public.html.

30. Theunis Bates, "Europe's Identity Crisis Fuels Rising Anti-Muslim Sentiment," America On Line News, (October 16, 2010), retrieved April 10, 2020, from https://wallscometumblingdown.wordpress. com/2010/12/06/article-europes-identity-crisis-fuels-rising-anti-muslim-sentiment/; Hans-Georg Betz and Susi Meret, "Revisiting Lepanto: The Political Mobilization against Islam in Contemporary Western Europe," Patterns of Prejudice, Vol. 43, No. 3 (2009), p. 313.

31. Jens Rydgren, "Radical Right-Wing Populism in Sweden and Denmark," SAIS Review, Vol. 30, No. 1 (December 2010) p. 2; See also, Jens Rydgren, "Explaining the Emergence of Radical Right-Wing Populist Parties: The Case of Denmark," West European Politics, Vol. 27, No. 3 (2004), pp. 474-502.

32. "Anti-Muslim Sentiment Is Becoming Institutionalized in West."

33. Jeanne Kay, "Europe's Islamophobia," Foreign Policy in Focus, (April 9, 2010), retrieved April 5, 2020, from http://www.fpif.org/articles/europes_islamophobia; John Hooper and Kate Connolly, "Berlusconi Breaks Ranks over Islam," The Guardian, (September 27, 2001), retrieved April 5, 2020, from http://www. guardian.co.uk/world/2001/sep/27/afghanistan.terrorism7.

34. Bates, "Europe's Identity Crisis Fuels Rising Anti-Muslim Sentiment."

35. Rydgren, "Radical Right-Wing Populism in Sweden and Denmark," p. 2.

36. Betz and Meret, "Revisiting Lepanto," p. 317.

37. Donna Lee Van Cott, "Institutional Change and Ethnic Parties in South America," Latin American Politics and Society, Vol. 45, No. 2 (2003), p. 1.

38. "Argentine Power Couple Loses Congressional Vote," CTV News, (June 29, 2009), retrieved April 10, 2020, from https://www.ctvnews.ca/argentine-power-couple-loses-congressional-vote-1.412258.

39. Jacinto, "Islam vs. Christianity in a Holy War?"

40. Jacinto, "Is Islam Endangering 'Europeannesess?"'; "The Use of Racist," p. 5.

41. Huntington, "The Clash of Civilizations?" p. 48.

42. Huntington, "The Clash of Civilizations?" pp. 22, 27.

43. Huntington, "The Clash of Civilizations?" pp. 23-24.

44. Huntington, "The Clash of Civilizations?" p. 40.

45. Huntington, "The Clash of Civilizations?" pp. 27, 40. 
46. Information retrieved from: http://www.worldvaluessurvey.org/wvs.jsp.

47. Inglehart and Welzel, Modernization, Cultural Change, and Democracy, p. 6.

48. Ronald Inglehart and Christian Welzel, "Modernization, Cultural Change, and Democracy: The Human Development Sequence,"World Values Survey, retrieved from http://www.worldvaluessurvey.org/ wvs/articles/folder_published/article_base_54. https://www.worldvaluessurvey.org/WVSDocumentationWV5.jsp

49. Ronald Inglehart and Pippa Norris, "The True Clash of Civilizations," Foreign Policy, Vol. 135 (MarchApril 2003), p. 65.

50. Inglehart and Norris, "The True Clash of Civilizations," pp. 64-65.

51. Inglehart and Welzel, Modernization, Cultural Change, and Democracy, p. 52.

52. "Cultural Map Wave 5," World Values Survey, (2008), retrieved from https://www.worldvaluessurvey. org/WVSContents.jsp?CMSID=Findings.

53. Huntington "The Clash of Civilizations?" p. 29; Inglehart and Norris, "The True Clash of Civilizations," p. 65.

54. Erling Høg and Helle Johannessen, "Denmark," Countries and Their Cultures, retrieved April 15, 2020, from http://www.everyculture.com/Cr-Ga/Denmark.html; Sven Tägil (ed.), Ethnicity and Nation Building in the Nordic World, (Carbondale, IL: Southern Illinois University Press, 1995), p. 20; Eva Ersbøll, "Country Report: Denmark," European University Institute, Robert Schuman Centre for Advanced Studies, and EUDO Citizenship Observatory, (April 2010), retrieved from https://cadmus.eui.eu/bitstream/handle/1814/19610/Denmark.pdf?sequence=1\&isAllowed=y, p. 1 .

55. Huntington, "The Clash of Civilizations?" p. 29.

56. Betz and Meret, "Revisiting Lepanto," pp. 318-319.

57. “Denmark's Immigration Issue," BBC News, (February 19, 2005), retrieved April 5, 2020, from http:// news.bbc.co.uk/2/hi/4276963.stm.

58. Betz and Meret, "Revisiting Lepanto," p. 322.

59. Jacinto, "Is Islam Endangering 'Europeannesess?"'; Alex Eichler, "Can Topless Women Keep Muslim Extremists Out of Denmark?" The Atlantic, (December 8, 2010), retrieved April 7, 2020, from https://www. theatlantic.com/international/archive/2010/12/can-topless-women-keep-muslim-extremists-out-ofdenmark/343113/.

60. Dan Bilefsky, "Cartoons Ignite Cultural Combat in Denmark," The New York Times, (January 1, 2006), retrieved April 9, 2020, from http://www.nytimes.com/2005/12/30/world/europe/30iht-islam9. html.

61. Sören Billing, "Mohammed Cartoons: A Decade of Controversy," The Local DK, (September 28, 2015), retrieved April 9, 2020, from https://www.thelocal.dk/20150928/denmarks-mohammed-cartoons-a-decade-in-the-news; Sten Rynning and Camilla Holmgaard Schmidt, "Muhammad Cartoons in Denmark: From Freedom of Speech to Denmark`s Biggest International Crisis since 1945," UNISCI Discussion Papers, No. 11 (May 2006), retrieved from https://www.redalyc.org/pdf/767/76701102.pdf, pp. 11-21.

62. Flemming Rose, "Why I Published Those Cartoons," The Washington Post, (February 19, 2006), retrieved March 30, 2020, from https://www.washingtonpost.com/wp-dyn/content/article/2006/02/17/ AR2006021702499.html

63. Anya Kublitz, "The Cartoon Controversy: Creating Muslims in a Danish Setting," Social Analysis, Vol. 54, No. 3 (Winter 2010), pp. 108, 113.

64. Teresa Küchler, "Gaza Gunmen Drag EU into Danish-Muslim Blasphemy Clash," Euobserver, (January 30, 2006), retrieved April 11, 2020, from https://euobserver.com/political/20799\#: :text=\%22We\%20 have\%20expressed\%20a\%20spirit,would\%20be\%20solved\%20through\%20\%22dialogue.

65. Seth Greenland, "Buy Danish," The Huffington Post, (February 7, 2006), retrieved April 10, 2020, from http://www.huffingtonpost.com/seth-greenland/buy-danish_b_15268.html.

66. Tägil, Ethnicity and Nation Building in the Nordic World, pp. 21-22. 
67. Nicola Miller, "The Historiography of Nationalism and National Identity in Latin America," Nations and Nationalism, Vol. 12, No. 2 (2006), p. 217.

68. Christoph Schumann, "Nationalism, Diaspora and 'Civilizational Mission': The Case of Syrian Nationalism in Latin America Between World War I and World War II," Nations and Nationalism, Vol. 10, No. 4 (2004), p. 599.

69. Miller, "The Historiography of Nationalism and National Identity in Latin America," p. 217.

70. Miller, "The Historiography of Nationalism and National Identity in Latin America," pp. 215-216.

71. Cecília Mariz and Rodrigo Freston, "Islam in Latin America," in Virginia Garrad-Burnett, Paul Freston, and Stephen Dove (eds.), The Cambridge History of Religions in Latin America, (Cambridge: Cambridge University Press, 2016), pp. 714-722; Jamal Arif, "Islam Under Wraps," Islami City, (June 11, 1999), retrieved April 11, 2020, from https://www.islamicity.org/221/islam-under-wraps/.

72. Ignacia Klich and Jeffrey Lesser, "Introduction: 'Turco' Immigrants in Latin America," The Americas, Vol. 53, No. 1 (1996), p. 9.

73. Gladys Jozami, "The Manifestation of Islam in Argentina," The Americas, Vol. 53, No. 1 (1996), p. 68; fn \#4.

74. Klich and Lesser, "Introduction," p. 10; Jozami, “The Manifestation of Islam in Argentina," p. 68; fn \#4.

75. Klich and Lesser, "Introduction,” p. 9-10.

76. Carmen Alicia Ferradás, "Argentina," Countries and Their Cultures, retrieved April 3, 2020, from http:// www.everyculture.com/A-Bo/Argentina.html.

77. Miller, "The Historiography of Nationalism and National Identity in Latin America," p. 205.

78. Inglehart and Norris, "The True Clash of Civilizations," p. 66.

79. Miller, "The Historiography of Nationalism and National Identity in Latin America," p. 216.

80. Klaus Dodds, "Stormy Waters: Britain, the Falkland Islands and UK-Argentine Relations," International Affairs, Vol. 88, No. 4 (July 2012), p. 684.

81. Dabéne, The Politics of Regional Integration in Latin America.

82. Miller, "The Historiography of Nationalism and National Identity in Latin America," p. 215.

83. Huntington "The Clash of Civilizations?" p. 35.

84. "Iran, Venezuela Leaders Seek 'New World Order,"' YNetNews, (October 20, 2010), retrieved April 15 , 2020, from https://www.ynetnews.com/articles/0,7340,L-3972676,00.html.

85. "US, Israeli Officials Slam Latin American Countries for Recognizing 'Palestine,'” Fox News, (December 8, 2010), retrieved April 15, 2020, from https://www.foxnews.com/politics/u-s-israeli-officials-slam-latin-american-countries-for-recognizing-palestine

86. Tägil, Ethnicity and Nation Building in the Nordic World, p. 9.

87. Huntington, "The Clash of Civilizations?" p. 49. 